\title{
The Effect of Varieties of Capitalism on the Relationship of Institutional Gearing and Economic Growth
}

\author{
Marisol Borges ${ }^{1}$, Edgar J. Saucedo-Acosta ${ }^{2}$, Jesus Diaz ${ }^{3}$ \\ ${ }^{1,2}$ University of Veracruz \\ 91190, Xalapa, Mexico \\ E-mail.marisol.borges@msev.gob.mx; esaucedo@uv.mx \\ ${ }^{3}$ Autonomous Metropolitan University-Iztapalapa \\ 09340, Mexico City, Mexico \\ E-mail.jdp@xamum.uam.mx
}

cross $^{\text {ref }}$ http://dx.doi.org/10.5755/j01.ee.31.3.22852

The ways the firm solves coordination problems with the different stakeholders (or the varieties of capitalism of nations) affect economic performance. Institutional gearing is one of the main determinants of economic growth. Nevertheless, there are no studies that analyse the effect of varieties of capitalism on the relationship of institutional gearing and economic growth. The objective of the paper is to estimate the effect of the variety of capitalism on the relationship between the institutional gearing index and other macroeconomic control variables on the GDP per capita in a group of developed and developing countries. To do that 3 panel data models were estimated: one with fixed effects and two with random effects, for 31 countries for the period 2011-2015. We used 16 Coordinated Market Economies and Liberal Market Economies and 15 Hierarchical Market Economies. The results showed the varieties of capitalism affect the relationship between institutional gearing and economic growth. In the Coordinated Market Economies and Liberal Market Economies this effect is higher than in Hierarchical Market Economies. Governments of Hierarchical Market Economies should not only apply public policies to build functional institutions, but also encourage the positive complementarities among them.

Keywords: Varieties of Capitalism; Institutional Gearing; Institutions; Economic Growth; Panel Data Model.

\section{Introduction}

The firm solves coordination problems with stakeholders in different ways. In some economies, the firm uses informal institutions to obtain agreements with labour unions and with the funding sources, while in other economies, the firm uses formal institutions to solve coordination problems. The first type of economies is named Coordinated Market Economies (CMEs) and the second one Liberal Market Economies (LMEs) (Hall \& Soskice, 2001). The CMEs solve firm coordination problems through surveillance and general trust, whereas the LMEs through laws and the markets. The institutions are the main driver of agent behaviour in CMEs and LMEs; those economies are developed countries where the rule of law prevails. Schneider (2009) points out that institutions are not the main driver of agent behaviour in Latin American economies and other developing economies, and their place is taken by organisations, such as: diversified business groups, multinationals, low-skilled labour and atomistic labour relations. Schneider (2009) named those economies as Hierarchical Market Economies (HMEs). The weak institutions in HMEs explain the low economic performance of the Latin American region and other developing economies, while the strong institutions of CMEs and LMEs explain their high economic growth. The type of economies of varieties of capitalism should be taken into account in the analysis of the determinants of economic growth.
Institutions play an important role in explaining long-run economic growth, because they induce the agent behaviour, such as investment decisions, consumption, etc. Borges, Saucedo-Acosta \& Diaz (2017) and Borges \& SaucedoAcosta (2018) define institutional gearing as positive institutional complementarities (Aoki, 1994) plus the spillover effect on the national innovation system. Therefore, institutional gearing affects economic growth. The relationship between institutional gearing and economic growth is affected by the variety of capitalism, because in some economies there are positive institutional complementarities (CMEs and LMEs) and in others negative ones (HMEs). In the LMEs and the CMEs, the existence of one institution (or sphere, according Hall and Soskice) increases the return of another, for instance, the existence of flexible labour markets, in LMEs, impacts positively on the sphere of corporate governance, and in the CMEs the existence of long-run trust agreements between firms and labour unions reduces the incentives for poaching. In the HMEs, the organisations take the role of institutions due to the weakness of the latter, and there are negative complementarities among organisations, for instance, the diversified business groups do not require high abilities in workers, therefore, they do not invest in themselves. The variety of capitalism should be taken into account when the relationship between institutional gearing and economic growth is analysed, in order to include the institutional differences among nations. 
Marisol Borges, Edgar J. Saucedo-Acosta, Jesus Diaz. The Effect of Varieties of Capitalism on the Relationship of ...

The effect of institutional gearing on economic growth is greater in economies with strong institutions, because such institutions induce the agent behaviour and increase the positive institutional complementarities. The nations with weak institutions, such as HMEs, have negative institutional complementarities and the organisations take decisions which are not optimal for the whole society, therefore, longrun economic growth is low. The Institutional gearing process requires strong institutions and positive institutional complementarities in order to influence innovation and economic growth.

There are papers using different methods to measure the effect of institutions on economic growth (Acemoglu et al., 2005; Esfahani \& Ramirez, 2003; Rodrik, 2000; Hall et al., 2010; Dias \& Tebaldi. 2012 and Kim et al., 2012) but such studies do not include the effect of institutional gearing, and this variable is quite important to explain the differentials of growth rates among countries. Other studies include the institutional gearing variable with panel data models (Borges, Saucedo-Acosta \& Diaz, 2017), which include the time and the cross-section data, but do not take into account the varieties of capitalism.

This paper has two contributions to literature. Firstly, there are no studies that analyse the effect of varieties of capitalism on the relationship of institutional gearing and economic growth, although there are studies that estimate the effect of institutional gearing and institutions on economic growth. Secondly, we introduce countries with positive and negative institutional complementarities to explain the rate of economic growth. Three panel data models were estimated, one for the whole sample and two for the varieties of capitalism (CMEs-LMEs and HMEs), and the Hausman test was applied showing that for the whole sample and CMEs-LMEs the best model was random effects and for the HMEs fixed effects were used. The data panel model includes the time and cross-section effects. The main objective of the paper is to include the effect of varieties of capitalism on the relationship of institutional gearing and GDP per capita. We are filling the gap of knowledge by including institutional gearing by group of countries (CMEs-LMEs and HMEs) with other macroeconomic control variables to estimate the effect on GDP per capita by using three panel data models from 20112015. There are many studies which have estimated the effect of institutions on economic growth, and recently they have included the effect of institutional gearing on economic growth, but have ignored the varieties of capitalism which explain economic growth.

\section{Literature Review}

\section{Institutions and Varieties of Capitalism}

According to North (1991), institutions are constraints (formal and informal) that help to establish interactions among economic agents. Such institutions reduce transaction costs and increase economic activities. Some authors (North, 1991; Williamson, 2000) have shown that the proper functioning of institutions (written and unwritten laws) help to establish better conditions for long-run economic growth.
The Varieties of Capitalism framework focuses on how the firm solves coordination problems. The firm interacts with stakeholders and has different relationships with them. According to Hall and Soskice (2001), developed countries can be divided into Liberal Market Economies (LMEs) and Coordinated Market Economies (CMEs). The firm, in the LMEs, solves coordination problems through formal institutions: written contracts, markets and competition. In CMEs, the firm solves coordination problems through informal institutions: surveillance, mutual trust, joint decision-making and strategic coordination. Amable (2003) expands the previous characterisation of the economies, and includes: Market Based (similar to LMEs), Continental European, Social Democratic, Mediterranean and Asian.

Hall and Soskice (2001) establish four spheres in which the firm solves coordination problems with stakeholders: corporate governance, inter-company relations, industry relations and education and training systems. The institutions (formal and informal) regulate the spheres and the firm solves coordination problems using institutions. Aoki (1994) points out the concept of institutional complementarity, which means that the existence of one institution increases the return of another institution. Hall and Soskice (2001) use this concept to establish complementarities among spheres, and those authors highlight the existence of positive institutional complementarities in CMEs and LMEs. Those complementarities explain the comparative institutional advancement of LMEs in services and the comparative institutional advantage of CMEs in advanced manufacturing, and in both cases explain their high economic growth.

Schneider (2009) establishes that institutions are not restrictions in many developed countries, and this role is taken by organisations. Those institutions are: diversified business groups, multinationals, atomised labour relations and low skills. Such organisations produce negative institutional complementarities and explain the low economic growth of many developing economies. Schneider (2009) names such capitalism as HMEs, with high levels of inequality and hierarchy relations, besides claiming that HMEs are mainly located in Latin America, Turkey and South East Asia. The HMEs have weak institutions, negative institutional complementarities and low levels of GDP pc. There are other varieties of capitalism for developing countries, for instance, Nolke and Vliegenthart (2009) suggest that many East Central European countries are Dependent Market Economies, because such countries have a high dependence on Foreign Direct Investment, even higher than HMEs.

Borges \& Saucedo-Acosta (2018) define institutional gearing as positive institutional complementarities (Aoki, 1994) plus the spillover effect on the national innovation system. Therefore, institutional gearing affects the economic growth of nations.

\section{Empirical Studies of Institutions and Other Macroeconomic Determinants of Economic Growth}

There are empirical studies that show, through different econometric models, the positive effects of institutions on economic growth (Acemoglu et al., 2005; Esfahani \& Ramirez, 2003; Rodrik, 2000). According to $\mathrm{Fu}$ et al., 
(2011) technology diffusion can only generate positive effects if there are national functional institutions. Institutions provide a regulatory framework that protects rights (Borges, Saucedo-Acosta \& Diaz (2017), a legal environment, and offer programmes and policies that motivate agents to innovate (Lundvall, 2010; Nelson, 1993; Nelson \& Nelson, 2002; Anderlini et al., 2013; Borges, Saucedo-Acosta \& Diaz , 2017).

Hall et al. (2010), Dias \& Tebaldi (2012) and Kim et al., (2012) point out the effect of institutions, human capital and capital stock on innovation. Kim et al. (2012) highlight that patent protection is a key element for innovation of developed countries, but not in developing countries (Borges, SaucedoAcosta \& Diaz, 2017), because institutions of developing countries benefit only a small group of people (Acemoglu \& Robinson, 2012; Buntaine et al., 2017), and lack a reliable and secure regulatory framework for agents involved in the various economic processes (Borges, Saucedo-Acosta \& Diaz, 2017).

Borges, Saucedo-Acosta \& Diaz (2017) have quantified, through a panel data model, a positive impact of institutional gearing on economic growth in developed and developing countries.

Kogan et al., (2017) point out technological innovation positively impacted the economic growth of the United States in the period 1926-2010. They used patents (forward citations) and the stock market, and their results are consistent with Schumpeterian predictions of the impact of creative destruction (innovation) on the economy. R\&D activities, human capital and capital stock are positively correlated to economic growth (Coe et al., 2009; Marroquin \& Rios, 2012; Sesay et al., 2018; Kacprzyk \& Doryn, 2017).

Yoo (2008), Aditya \& Acharyya (2013), Lee (2011), Can \& Gozgor (2018) estimate a relationship between high technology exports and exports diversification with innovation and economic growth, in which institutions are key elements. Lee (2011) estimates the relationship of high technology exports and the economic growth of 71 developed and developing countries. Such author found that high technology exports affects positively to economic growth Aditya and Acharyya (2013) find diversification, composition and high technology exports as determinants of economic growth.

Several papers show the links between innovations and economic growth (Schumpeter, 2010; Romer, 1990; Grossman \& Helpman, 1991; Aghion \& Howitt, 1998; Nelson, 2007; Segerstrom, 1991; Wong, et al., 2005). Some studies find a positive effect of innovation on economic growth (Coe et al., 2009; Marroquin \& Rios, 2012; Sesay et al., 2018; Kacprzyk \& Doryn, 2017). However, some authors have found unclear evidence for the previous variables for specific regions (Benhabib \& Spiegel, 1994; Ulku, 2007). Benhabib \& Spiegel (1994) find a negative and non-significant relationship between human capital dynamics and economic growth. These authors point out that in countries with low levels of human capital (developing countries), an increase in this variable generates a high rate of human capital. However, this increase is not correlated with high economic growth. Therefore, an increase in human capital dynamics is not related with the economic growth of developing countries.

\section{Data and Methodology}

\section{Data}

This paper estimates the effect of institutional gearing on GDP per capita according to different varieties of capitalism. The time series data were used from 2011 to 2015 from the Penn World Table 9.1 (Feenstra, Inklaar \& Timmer, 2015), World Development Indicators (World Bank, 2018) and Borges, Saucedo-Acosta \& Diaz (2017). GDP per capita was used (current US\$) as a dependent variable, whereas the institutional gearing index, human capital index, gross capital formation (\%GDP), high technology exports (current US dollars) and gross domestic expenditures on research and development (\%GDP) as independent variables.

Countries from different varieties of capitalism were used. Both Hall and Soskice (2001) and Schneider's (2009) classifications of capitalism were considered and 15 CMEs and LMEs and 16 HMEs were included in the paper.

\section{Econometric Model}

With the available data, a panel data from 2011 to 2015 was built for 15 Latin America countries (Hierarchical Market Economies), 10 coordinated countries (Coordinated Market Economies) and 6 liberal countries (Liberal Market Economies), like the countries used by Schneider \& Karcher (2010). It is a short period of time, but the institutional gearing series is short, because it is new and depends on other variables (Borges, Saucedo-Acosta \& Diaz, 2017). The general panel specification is the following (Hsiao, 2014; Saucedo-Acosta, Molina \& Diaz, 2016):

$$
\begin{aligned}
& y_{i t}=\mu_{i t}+X_{i t} \beta_{i t}+u_{i t} \quad \text { for } \mathrm{i}=1,2, \ldots, \mathrm{N} \\
& \text { and } \mathrm{t}=1,2, \ldots \mathrm{T}
\end{aligned}
$$

Where $\mu_{i t}$ and $\beta_{i t}$ are vectors with dimensions $1 \times 1$ and $1 \times \mathrm{K}$.

Using panel data, it is possible to capture non-observable heterogeneity, such as cross-section analysis and time series analysis (Wooldridge, 2010; Saucedo-Acosta, Molina \& Diaz, 2016). Some authors analyse the effect of institutions on economic growth (Kapas \& Czegledi, 2017; Hall, et al., 2010; Dias \& Tebaldi, 2012; Kim et al., 2012) and others the impact of knowledge, human capital, investment in R\&D activities and high-technology exports on innovation and economic growth (Aditya \& Acharyya, 2013; Coe et al., 2009; Fu et al., 2011; Marroquin \& Rios, 2012; (Borges, Saucedo-Acosta \& Diaz, 2017). The following equations were estimated:

Entire sample

gdppc $_{\text {it }}=\beta_{0}+\beta_{1} i g_{i t}+\beta_{2} h c_{i t}+\beta_{3} g k f_{i t}+\beta_{4} h t m_{i t}+$ $\beta_{5} r \& d_{i t}+\mu_{i t} \ldots(2)$

CMEs and LMEs

$\operatorname{gdppc}_{\mathrm{it}}=\beta_{0}+\beta_{1} i g_{i t}+\beta_{2} h c_{i t}+\beta_{3} g k f_{i t}+\beta_{4} h t m_{i t}+$ $\beta_{5} r \& d_{i t}+\mu_{i t} \ldots(3)$

HMEs

gdppc $_{\text {it }}=\beta_{0}+\beta_{1} i g_{i t}+\beta_{2} h c_{i t}+\beta_{3} g k f_{i t}+\beta_{4} h t m_{i t}+$ $\beta_{5} r \& d_{i t}+\mu_{i t} \ldots(4)$

where:

$\mathrm{t}$ is time period and $\mathrm{i}$ is the country.

$\mu_{i t}$ is the error term, 
Marisol Borges, Edgar J. Saucedo-Acosta, Jesus Diaz. The Effect of Varieties of Capitalism on the Relationship of ...

gdppc: is the aggregation of gross value added divided by population. The gdppc is in current US dollar.

ig: is a variable that measures how the institutions work together. It was estimated by Borges, Saucedo-Acosta \& Diaz (2017). The data vary from 0 to 100 , where 100 is the highest level of institutional gearing and 0 is the lowest.

hc: is the human capital index. This index is estimated based on years of schooling and returns to education.

gkf is gross capital formation, it includes the fixed assets and the changes in inventories. The data are expressed in \% GDP.

htm: are high technology exports, products with R\&D intensity. htm are expressed in current US dollars.

r\&d: is gross domestic expenditures on research and development and includes capital and current expenditures. The data are expressed in \% GDP.

Table 1 shows some statistics of the dependent and independent variables, with different groups according the varieties of capitalism and the entire sample of countries. The CMEs and LMEs group have higher levels, on average, of almost all variables, because this group includes developed countries, whereas the HMEs group are developing countries from Latin America. On average, the CMEs and LMEs have a GDP per capita of 55 thousand dollars and the HMEs have a GDP per capita of 7800 dollars. The value of the institutional gearing indicator is higher for the CMEs and LMEs (69) than the HMEs group (36).

Table 1

Descriptive Statistics

\begin{tabular}{|c|r|r|r|r|r|}
\hline Variable & Obs. & \multicolumn{1}{c|}{ Mean } & \multicolumn{1}{c|}{ Std. Dev. } & \multicolumn{1}{c|}{ Min. } & \multicolumn{1}{c|}{ Max. } \\
\hline \multicolumn{7}{|c|}{ All countries } \\
\hline GDPpc & 155 & 31082.88 & 26552.84 & 1679.74 & 102910.40 \\
\hline IG & 155 & 52.44 & 17.73 & 21.27 & 79.39 \\
\hline Hc & 155 & 2.99 & 0.53 & 1.78 & 3.74 \\
\hline GKF & 155 & 22.83 & 5.18 & 13.62 & 44.30 \\
\hline HTM & 154 & $3.09 \mathrm{e}+10$ & $5.14 \mathrm{e}+10$ & 226153 & $2.16 \mathrm{e}+11$ \\
\hline R\&D & 137 & 1.43 & 1.19 & 0.01 & 3.63 \\
\hline \multicolumn{7}{|c|}{ CMEs \& LMEs } \\
\hline GDPpc & 75 & 55909.49 & 15332.70 & 34523.7 & 102910.40 \\
\hline IG & 75 & 69.00 & 4.24 & 58.77 & 79.39 \\
\hline Hc & 75 & 3.47 & .20 & 3.04 & 3.74 \\
\hline GKF & 75 & 22.33 & 3.06 & 15.70 & 28.06 \\
\hline HTM & 75 & $5.84 \mathrm{e}+10$ & $6.13 \mathrm{e}+10$ & $4.25 \mathrm{e}+0$ & $2.16 \mathrm{e}+11$ \\
\hline R\&D & 70 & 2.48 & 0.66 & 1.19 & 3.63 \\
\hline \multicolumn{7}{|c|}{ HMEs } \\
\hline GDPpc & 80 & 7807.92 & 4523.53 & 1679.74 & 16881.38 \\
\hline IG & 80 & 36.92 & 9.58 & 21.27 & 62.15 \\
\hline Hc & 80 & 2.54 & 0.32 & 1.78 & 3.07 \\
\hline GKF & 80 & 23.31 & 6.56 & 13.62 & 44.30 \\
\hline HTM & 79 & $4.82 \mathrm{e}+09$ & $1.43 \mathrm{e}+10$ & 226153 & $6.29 \mathrm{e}+10$ \\
\hline R\&D & 67 & 0.34 & 0.31 & 0.01 & 1.34 \\
\hline \multicolumn{7}{|c|}{ Sources: own elaboration } \\
\hline
\end{tabular}

For the entire sample the Hausman test was applied and the value of the probability of chi2 was higher than 0.05 , therefore the random effects model was applied. Besides, the Wooldridge test was used to detect autocorrelation, but no such problem was found. Finally, a robust random effect model was carried out. The same procedure was applied for the CMEs and LMEs group and the model applied was the same.

For the HMEs group the Hausman test was applied and the value of the probability of Chi2 was lower than 0.01 , therefore the fixed effects was applied. Besides, the Wooldridge test was used to detect autocorrelation and the Modified Wald test heteroskedasticity, and those tests showed that there are both problems. Finally, a Prais-Winsten regression was carried out to correct the previous problems.

\section{Results}

Figure 1 shows the relationship between the GDP per capita and the institutional gearing indicator. According to this figure there is a positive relationship between both variables.

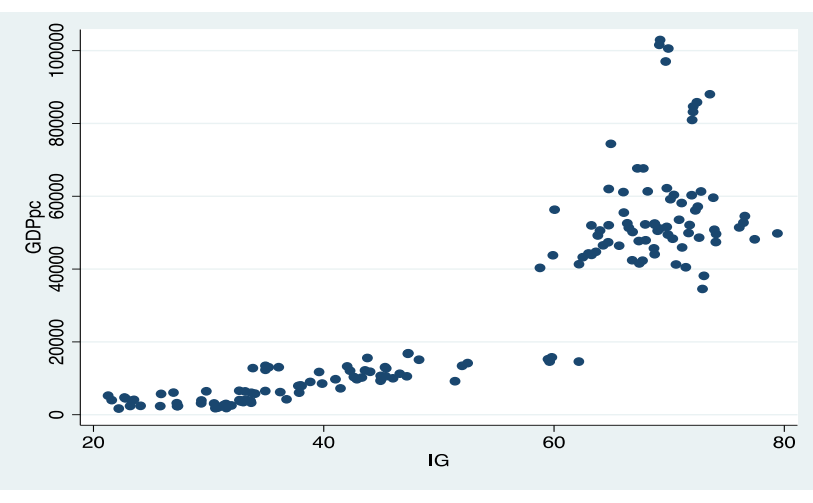

Figure 1. GDP per Capita and Institutional Gearing in the Entire Sample

Table 2 shows the results from estimating equation (2) with the random effects model, using the entire sample of countries. A regression was run between the GDPpc, institutional gearing and a set of control variables. The findings suggest that institutional gearing is positively correlated with GDPpc, so higher institutional complementarities among institutions lead to higher economic growth. The coefficient of institutional gearing is positive (696) and significant at $1 \%$. The human capital indicator is positively related with economic growth, because the coefficient is positive (17009) and significant at $5 \%$. The coefficient of gross capital formation is positive and significant at $10 \%$. Finally, high technology exports and the gross domestic expenditures on research and development are not significant.

Table 2

Economic Growth, Institutional Gearing and Control Variables for the Entire Sample: Panel Estimation

\begin{tabular}{|c|c|c|c|}
\hline GDPpc & Coef. & $\mathbf{P}$ & s.e. \\
\hline IG & 696 & 0.000 & 189 \\
\hline $\mathrm{Hc}$ & 17009 & 0.036 & 8110 \\
\hline GKF & 390.9776 & 0.050 & 199 \\
\hline HTM & $-8.89 \mathrm{e}-08$ & 0.158 & $6.80 \mathrm{e}-08$ \\
\hline R\&D & 4008 & 0.691 & 5164 \\
\hline Constant & -66700 & 0.005 & 23315 \\
\hline Hausman test & 5.60 & 0.230 & Prob>chi2 \\
\hline R-sq (within) & 0.2879 & & \\
\hline R-sq (between) & 0.7047 & & \\
\hline R-sq (overall) & 0.6879 & & \\
\hline Wald (chi-sq) & 101.62 & 0.000 & Prob $>$ chi2 \\
\hline Observations & 137 & & \\
\hline
\end{tabular}

Table 3 shows the results from estimating equation (3) with the random effects model, using the CMEs and LMEs group of countries. A regression was run between the GDPpc, institutional gearing and a set of control variables. The findings suggest that institutional gearing is positively 
correlated with GDP per capita, so higher institutional complementarities among institutions lead to higher economic growth in CMEs and LMEs. The coefficient of institutional gearing is positive (1107) and significant at 1 $\%$. The human capital indicator and the gross capital formation are positively related with economic growth and significant at $1 \%$. The coefficients of high technology exports (-7.07e-08) and expenditure on research and development activities (-6814) are negatively related with the GDP per capita.

Table 3

Economic Growth, Institutional Gearing and Control Variables for the CMEs and LMEs Group: Panel Estimation

\begin{tabular}{|l|r|r|r|}
\hline \multicolumn{1}{|c|}{ GDPpc } & Coef. & P & \multicolumn{1}{c|}{ s.e. } \\
\hline IG & 1107 & 0.000 & 119 \\
\hline Hc & 15704 & 0.000 & 3402 \\
\hline GKF & 2045 & 0.000 & 269 \\
\hline HTM & $-7.07 \mathrm{e}-08$ & 0.000 & 1430 \\
\hline R\&D & -6814 & 0.000 & Prob>chi2 \\
\hline Constant & -100506 & 0.000 & \\
\hline Hausman test & 0.08 & 0.9993 & \\
R-sq (within) & 0.4629 & & Prob>chi2 \\
R-sq (between) & 0.6237 & & \\
R-sq (overall) & 0.4655 & & \\
Wald (chi-sq) & 101.62 & 0.000 & \\
Observations & 70 & & \\
\hline
\end{tabular}

$P=$ robust standard error

Standard errors adjusted for 5 clusters in Year Random effects

Table 4 shows the results from estimating equation (4) with the fixed effects model, using the HMEs. A regression was run between the GDPpc, institutional gearing and a set of control variables. Institutional gearing is positively related with GDPpc per capita in Latin American countries, so the positive institutional complementarities among institutions lead to higher economic growth in developing countries, but the coefficient is lower in HMEs (209) than in the CMEs and LMEs group (1107). The human capital indicator is positively related with the GDPpc and lower in HMEs (6267) than in the CMEs and LMEs group (15704). The gross capital formation, the high technology exports and the expenditure on research and development activities is not significant in HMEs.

Table 4

Economic Growth, Institutional Gearing and Control Variables for HMEs: Panel Estimation

\begin{tabular}{|l|l|l|l|}
\hline \multicolumn{1}{|c|}{ GDPpc } & \multicolumn{1}{c|}{ Coef. } & \multicolumn{1}{c|}{ P } & \multicolumn{1}{c|}{ s.e. } \\
\hline IG & 209 & 0.000 & 29 \\
\hline Hc & 6267 & 0.000 & 1067 \\
\hline GKF & -71 & 0.143 & 48 \\
\hline HTM & $-8.47 \mathrm{e}-09$ & 0.330 & $8.70 \mathrm{e}-09$ \\
\hline R\&D & 1881 & 0.212 & 1506 \\
\hline Constant & -14582 & 0.000 & 1971 \\
\hline Hausman test & 24.462 & 0.0003 & Prob>chi2 \\
R-sq & 0.7845 & & Prob>chi2 \\
Wald (chi-sq) & 330.94 & 0.000 & \\
Observations & 67 & & \\
\hline
\end{tabular}

$P=$ standard error

Fixed effects

Autocorrelation and heteroskedasticity problem corrected with PraisWinsten regression

\section{Discussions and Conclusions}

Institutions play a very important role in the performance of nations. The way in which institutions work together is also a determinant of economic growth. Institutional gearing and varieties of capitalism should explain why some countries grow faster than others. The aim of the paper was to estimate the effect of institutional gearing on economic growth according to the different varieties of capitalism. The CMEs and LMEs group have different characteristics than the HMEs, and the most important distinctness is the weak institutions in the HMEs. We obtained results related to the objectives of the paper, because through three panel data models, the effect of institutional gearing on economic growth was estimated for the CMEs and LMEs group and HMEs. Using panel data models with different groups of countries provides the advantage that includes the temporal, cross-section effects and the variety of capitalism to explain economic growth. The results show that economic growth is positively affected by institutional gearing, and according to the varieties of capitalism this effect is different.

The coefficients of institutional gearing, human capital and gross capital formation are positive for the entire sample, which means such variables positively affect economic growth. Nevertheless, the coefficient of high technology exports and investment in R\&D activities are not significant. For the CMEs and LMEs group institutional gearing, human capital and gross capital formation positively affect economic growth, whereas high technology exports and investment in R\&D activities negatively affect economic growth. Finally, for HMEs the economic growth is positively affected by institutional gearing and human capital, the other variables are not significant.

Our results are innovative, because for the first time the effect of institutional gearing on economic growth was estimated according to the varieties of capitalism. The results are similar to Borges, Saucedo-Acosta \& Diaz (2017), because they estimate the effect of institutional gearing on economic growth, but without taking into account the varieties of capitalism. Also, the results have similarities to some papers (Coe et al., 2009; Marroquin and Rios, 2012). However, the negative coefficient of investment in R\&D activities in the CMEs and LMEs group does not coincide with most studies for developed countries, but agrees with other studies for developing countries (Benhabib \& Spiegel, 1994; Ulku, 2007). The previous relationship can be explained because investment in R\&D activities depends on the level of education, the number of researchers and absorption capacities (Benhabib \& Spiegel, 1994). Besides economic growth rates increase more than R\&D spending in developed countries and vice versa in developing countries (Borges, Saucedo-Acosta \& Diaz, 2017).

Including the institutional gearing variable and varieties of capitalism strengthens the neo-institutionalism and the varieties of capitalism theory. In this sense, proper and interrelated institutions allow economies to grow faster (North, 1981, 1991; Lundvall, 2010; Edquist \& Johnson, 1997; Rodrik, 2000; Acemoglu et al., 2005; Hall et al., 2010; Dias \& Tebaldi, 2012; Kim et al., 2012), and positive institutional complementarities (CMEs and LMEs) produce 
Marisol Borges, Edgar J. Saucedo-Acosta, Jesus Diaz. The Effect of Varieties of Capitalism on the Relationship of ...

comparative institutional advantages and higher economic growth.

This paper used a short period of time (2011-2015), because the institutional gearing index did not contain many years, which may not be enough to obtain conclusive results. Nevertheless, it is the first time that the concept of institutional gearing (new in economic science) has been applied to different varieties of capitalism, so we consider that this paper is a significant contribution to the studies of interaction between economic growth and institutions and the varieties of capitalism framework.

The improvement of institutional gearing is suggested through creating institutions with positive complementarities among them. For HMEs building strong institutions is suggested to influence the agents' behaviour.
Besides, the governments of the HMEs should consider following one of the CMEs or LMEs paths, in order to create positive institutional complementarities and boost institutional gearing.

This paper explored the relationship of institutional gearing, human capital, gross capital formation, high technology exports and investment in R\&D activities with GDPpc growth rates for the CMEs and LMEs group and HMEs. It was shown that CMEs and LMEs have had higher levels of institutional gearing than HMEs, and also the advanced economies grow faster. Besides, institutional gearing positively affects the GDP per capita and it does not matter if the entire sample is used, the CMEs and LMEs group or the LMEs.

\section{References}

Acemoglu, D., Johnson, S., \& Robinson, J. A. (2005). Institutions as a fundamental cause of long-run growth. In P. Aghion \& S. Durlauf (Ed.), Handbook of economic growth (385-472). Amsterdam: Elsevier Inc. https://doi.org/10. 1016/S1574-0684(05)01006-3

Acemoglu, D., \& Robinson, J. (2012). Why Nations Fail: The Origins of Power and Poverty. New York: Crown. https://doi.org/10.1355/ae29-2j

Aditya, A., \& Acharyya, R. (2013). Export diversification, composition, and economic growth: Evidence from crosscountry analysis. The Journal of International Trade \& Economic Development: An International and Comparative Review, 22(7), 959-992. https://doi.org/10.1080/09638199.2011.619009

Aghion, P., \& Howitt, P. (1998). Endogenous Growth Theory. Cambridge: The MIT Press.

Amable, B. (2003). The Diversity of Modern Capitalism, Oxford: Oxford University Press. https://doi.org/10.1093/ 019926113X.001.0001

Aoki, M. (1994). 'The Contingent Governance of Teams: An Analysis of Institutional Complementarity', International Economic Review, 35, 657-676. https://doi.org/10.2307/2527079

Anderlini, L, Felli, L., Immordino, G., \& Riboni, A. (2013). Legal Institutions, Innovation, and Growth. International Economic Review, 54 (3), 937-956. https://doi.org/10.1111/iere.12023

Benhabib, J., \& Spiegel, M. (1994). The role of human capital in economic development evidence from aggregate crosscountry data. Journal of Monetary economics, 34(2), 143-173. https://doi.org/10.1016/0304-3932(94)90047-7

Borges, M., \& Saucedo-Acosta, E. (2018). Una aproximacion a la creacion del constructo de engranaje institucional como elemento del enfoque sistemico de la innovacion, Ciencia UAT, 12 (1), 78-89. https://doi.org/10.29059 /cienciauat.v12i 2.846

Borges, M., Saucedo-Acosta, E., \& Diaz, J. (2017) Institutional gearing, innovation and economic growth: empirical estimation for 32 economies, Dubrovnik International Economic Meeting, 3 (1), 207-218.

Buntaine, M., Parks, B., \& Buch, B. (2017). Aiming at the Wrong Targets: The Domestic Consequences of International Efforts to Build Institutions. International Studies Quarterly, 61 (2), 471-488. https://doi.org/10.1093/isq/sqx013

Can, M., \& Gozgor, G. (2018). Effects of export product diversification on quality upgrading: an empirical study. The Journal of International Trade \& Economic Development: An International and Comparative Review, 23(3), 293313. https://doi.org/10.1080/09638199.2017.1370006

Coe, D., Helpman, E., \& Hoffmaister, W. (2009). International R\&D spillovers and institutions. European Economic Review, 53(7), 723-741. https://doi.org/10.1016/j.euroecorev.2009.02.005

Dias, J., \& Tebaldi, E. (2012). Institutions, human capital, and growth: The institutional mechanism. Structural Change and Economic Dynamics, 23(3), 300-312. https://doi.org/10.1016/j.strueco.2012.04.003

Edquist, C., \& Johnson, B. (1997). Institutions and organisations in systems of innovation. In C. Edquist, (Ed.) Systems of Innovation: Technologies, Institutions and Organizations. London and Washington: Pinter. 
Esfahani, H. S., \& Ramirez, M. T. (2003). Institutions, infrastructure, and economic growth. Journal of Development Economics, 70(2), 443-477. https://doi.org/10.1016/S0304-3878(02)00105-0

Feenstra, Robert C., Robert Inklaar, \& Marcel P. Timmer. (2015). The Next Generation of the Penn World Table. American Economic Review, 105 (10), 3150-82. https://doi.org/10.1257/aer.20130954

Fu, X., Pietrobelli, C., \& Soete, L. (2011). The role of foreign technology and indigenous innovation in the emerging economies: technological change and catching-up. World Development, 39(7), 1204-1212. https://doi.org/10. 1016/j.worlddev.2010.05.009

Grossman, G., \& Helpman, E. (1991). Innovation and growth in the global economy. Cambridge: The MIT Press.

Hall, J. C., Sobel, R. S., \& Crowley, G. R. (2010). Institutions, capital, and growth. Southern Economic Journal, 77(2), 385-405. https://doi.org/10.4284/sej.2010.77.2.385

Hall, P., \& Soskice, D. (2001). Introduction. In Hall, P. \& Soskice, D. (eds) Varieties of Capitalism. The Institutional Foundations of Comparative Advantage. Oxford: Oxford University Press, 1-68. https://doi.org/10.1093/019924 7757.003.0001

Hsiao, C. (2014). Analysis of panel data. Cambridge: Cambridge University Press. https://doi.org/10.1017/ CBO9781139839327

Kacprzyk, A., \& Doryn, W. (2017). Innovation and Economic Growth in Old and New Member States of the European Union. Economic Research-Ekonomska Istrazivanja, 30 (1), 1724-1742. https://doi.org/10.1080/1331677X. 2017.1383176

Kapas, J., \& Czegledi, P. (2017). Institutions and policies of economic freedom: different effects on income and growth. Economia Politica, 34 (2), 259-282. https://doi.org/10.1007/s40888-017-0063-5

Kim, K., Lee, K., Park, W., \& Choo, K. (2012). Appropriate intellectual property protection and economic growth in countries at different levels of development. Research policy, 41, 358-375. https://doi.org/10.1016/ j.respol.2011.09.003

Kogan, L., Papanikolaou, D., Seru, A., \& Stoffman, N. (2017). Technological innovation, resource allocation, and growth. Quarterly Journal of Economics, 132 (2), 665-712. https://doi.org/10.1093/qje/qjw040

Lee, J. (2011). Export specialization and economic growth around the world. Economic Systems, 35, 45-63. https://doi.org/10.1016/j.ecosys.2010.11.002

Lundvall, B. (2010). National Systems of Innovation: Toward a theory of innovation and interactive learning. London: Anthem Press. https://doi.org/10.7135/UPO9781843318903

Marroquin, A. J., \& Rios B. H. (2012). Inversion en investigacion y crecimiento economico: un analisis empirico desde la perspectiva de los modelos de I+D. Investigacion economica, 21(282), 15-33.

Nelson, R. (1993). National innovation systems. London: Oxford University Press.

Nelson, R., \& Nelson, K. (2002). Technology, institutions, and innovation systems. Research Policy, 30 (2), $265-272$. https://doi.org/10.1016/S0048-7333(01)00140-8

Nelson, R. (2007). Understanding Economic growth as the central task of economic analysis, Perspectives on innovation. New York: Cambridge University Press.

Nolke, A., \& Vliegenthart, A. (2009). Enlarging the Varieties of Capitalism: The Emergence of Dependent Market Economies in East Central Europe. World Politics, 61(4), 670-702. https://doi.org/10.1017/S0043887109990098

North, D. (1981). Structure and Change in Economic History, New York: Norton.

North, D. (1991). Institutions. Journal of Economic Perspectives, 5 (1), 97-112. https://doi.org/10.1257/jep.5.1.97

Rodrik, D. (2000). Institutions for high-quality growth: what they are and how to acquire them. Studies in Comparative International Development, 35 (3), 3-31. https://doi.org/10.1007/BF02699764

Romer, P. (1990). Endogenous Technological Change. Journal of Political Economy, 98, 71-102. https://doi.org/10. $1086 / 261725$

Saucedo-Acosta, E., Molina, R. \& Diaz, J. (2016). Variedades del capitalismo y desigualdad en el ingreso en los paises de la OCDE.

Sesay, B., Zhao, Y., \& Wang, F. (2018). Does the national innovation system spur economic growth in Brazil, Russia, India, China and South Africa economies? Evidence from panel data. South African Journal of Economic and Management Sciences, 21, 1-12. https://doi.org/10.4102/sajems.v21i1.1647 
Marisol Borges, Edgar J. Saucedo-Acosta, Jesus Diaz. The Effect of Varieties of Capitalism on the Relationship of ...

Segerstrom, P. S. (1991). Innovation, Imitation, and Economic-Growth. Journal of Political Economy, 99 (4), $807-827$. https://doi.org/10.1086/261779

Schneider, B. (2009). Hierarchical Market Economies and Varieties of Capitalism in Latin America. Journal of Latin American Studies 41(3), 553-575. https://doi.org/10.1017/S0022216X09990186

Schneider, B. R., \& Karcher, S. (2010). Complementarities and Continuities in the Political Economy of Labour Markets in Latin America. Socio-economic Review, 8(4), 623-51. https://doi.org/10.1093/ser/mwq022

Schumpeter, J. (2010). Capitalism, Socialism and Democracy. eBook. London: Routledge. https://doi.org/10.4324/ 9780203857090

Ulku, H., (2007). R\&D, innovation and output: evidence from OECD and non OECD countries. Applied Economics, 39 (3), 291-307. https://doi.org/10.1080/00036840500439002

Williamson, O. E. (2000). The New Institutional Economics: Taking Stock, Looking Ahead. Journal of Economic Literature, 38 (3), 595-613. https://doi.org/10.1257/jel.38.3.595

Wong, P. X., Ho, Y. P., \& Autio, E. (2005). Entrepreneurship, innovation and economic growth: Evidence from GEM data. Small Business Economics, 24 (3), 335-350. https://doi.org/10.1007/s11187-005-2000-1

Wooldridge, J. (2010). Econometric Analysis of Cross Section and Panel Data. 2nd edition, MIT Press, Cambridge.

World Bank. (2018). World Bank Open Data. Available from Internet: https://data.worldbank.org/

Yoo, S. H. (2008). High-technology exports and economic output: an empirical investigation. Applied Economic Letters, 15 (7), 523-525. https://doi.org/10.1080/13504850600721882

The article has been reviewed.

Received in February 2019; accepted in June 2020. 